\title{
The Cameroon Displacement: A Neglected Crisis
}

\author{
Hugh Kang
}

\author{
Seoul International School \\ kanghugh09@gmail.com
}

$\mathrm{DOI}<10.26821 / \mathrm{IJSRC} .8 .9 .2020 .8905>$

\begin{abstract}
My paper examines the neglect that the Cameroonian Crisis faces in three different domains: international, domestic, and organizational. The paper conducts a comparative analysis between the Cameroonian Crisis and the Somalian Crisis to demonstrate the vast contrast in media coverage and aid packages between the two crises. It unveils the social, economic, and historical factors that account for this gap, placing the Somalian crisis on the frontlines of global attention and preventing the Cameroonian crisis from receiving comparable treatment.

From an international standpoint, the paper focuses on the responses from neighboring African countries. More importantly, the effectiveness and integrity of these initiatives are revealed, with many false promises and a lack of follow-up. Countries like Equatorial Guinea, South Africa, and Côte d'Ivoire could potentially help Cameroon; this capacity is analyzed by studying the political and economic factors that will either aid or possibly obstruct any future attempts to help Cameroon.
\end{abstract}

The paper also examines the implosion of domestic infrastructures that led to the Cameroonian crisis, as well as the historical factors that led to the displacement of thousands of people. The crisis is notably neglected by large international organizations such as the UNHCR; the paper delves into the lack of follow-through on set objectives, the failure of unrealistic goals, and the dangers of neglect by these international

bodies.

The paper ultimately outlines a concrete plan of action that calls for international dialogue to tackle the complexity of the issue through a constellation of

Hugh Kang, Vol 8 Issue 9, pp 36-44 September 2020 international initiatives, national reforms, and scaled responses that give the Cameroonian crisis the awareness and support it deserves.

Keywords: displacement, human rights, refugee, neglect, negotiation, dialogue, intervention,

\section{INTRODUCTION}

Aid workers from the Norwegian Refugee Council listed Cameroon as one of the world's most neglected displacement crises. This came after two conflicts in the region resulted in killings, burning of villages, and displacement of 600,000 people from their homes [19]. The crisis in Cameroon requires international intervention as the people are already facing increased risks of attacks, abandonment, and displacement. In response, different organizations such as the International Crisis Group attempted to de-escalate conflict in Cameroon and encourage a resolution of the conflict. However, notwithstanding the interception, the conflict still haunts the people of Cameroon, who face the possibility of suffering from a full-blown war. Despite being more imminent than other crises, the Cameroon Displacement does not receive the international, domestic, and organizational attention and aid that it deserves.

\section{INTERNATIONAL NEGLECT}

The neglect of the crisis in Cameroon can most clearly be seen through the international attention that it receives. Cameroon is part of the African Union, which is a continent-wide body that consists of 55 different countries in the African continent cohesively focusing on the promotion of African solutions to African problems. This was discussed at The Peace and Security Council of the African Union, where it 
Volume 8 Issue 9 September 2020

was surmised that the challenges in the African region do not require external meddling. However, according to clause five of the communique, the African Union would focus on the upholding of African solutions to African problems. This was a principle that was adopted by the African Union, although critics suggest that this resolution fails to address important issues. A closer examination of the efforts aimed at preventing, managing, and resolving conflicts and crises in Africa, reveals that it still requiressignificant international assistance. This is given that the conflicts in Africa, such as those that recently occurred in Cameroon are considered as an international threat that calls for an international response. However, despite the apparent threat throughout the Cameroon Crisis, both the United Nations and the African Union have refused to acknowledge and confront the issue.

First of all, the United Nations Security Council (UNSC) failed to issue any public statements about the severe human rights abuses ongoing in the Cameroonian region. There have been severe human rights violations by both the governmental military and the separatist group in Cameroon (which will be investigated in a later paragraph), yet no initiative has been taken to warn either side of the consequences of violating such human rights.

There have been efforts by the United Nations of a possible robust action to be taken to address the issue at hand. For instance, in May 2019, the United States of America organized an informal meeting of Security Council members with a focus on designating the Cameroonian crisis on the Security Council's priority list. They were able to do this in collaboration with member states like Germany, Dominican Republic, and the United Kingdom. Despite the effort, two factors caused the overall initiative to be incredibly ineffective: The informality of the event and the resistance of the African Union. Held solely as an informal event, causing many of the discussions and agreements to be non-binding. Additionally, the members of the Council of Africa were against any direct Western intervention in their continent, even causing the permanent Security Council representative of the African Union to not attend the session.

If this resistance is taken into account, designated nonWestern parties must take lead in the process of getting Cameroon on the agenda of the Security Council. However, many of the African Union have shown disinterest, neglect, or inaptitude in being able to take this role in mobilizing the Security Council towards combatting this issue.
Equatorial Guinea, one of the members of the African Union, is unlikely to take this role, given that even within its domestic borders, the nation is deep into its rampant human rights violations, including arbitrary detention, ill-treatment, and torture of civilians and politicians. Being focused on the country's domestic issues, there is little rationale to believe that they would attempt to focus on the issues within another nation's borders, regardless of the threats to the security or human rights.

South Africa has historically been known as a nation that has been actively supporting initiatives taken in the Security Council, especially since their struggle against the apartheid involved international solidarity. However, the series of recent presidents have been pushing back any international efforts of addressing the issues of human rights violations in African countries such as Zimbabwe, Sudan, and Myanmar. Regardless, the current South African president, Cyril Ramaphosa, has stated his focus on "democracy, justice, human rights, and good governance" within the member states of the United Nations, so aid could be expected in the future.

Côte d'Ivoire is also an African nation that has the potential to turn towards the Cameroonian Crisis but has yet to takeaction. As a part of his 2016 campaign, President AlassaneOuattara has stated that the United Nations "must be the principal organ in which courageous decisions are taken, to save people and states from conflicts and wars, with the suffering and distress that they bring". As a part of their membership in the Security Council, they have taken leadership on human rights issues, including initiation of the placement of an arms embargo on South Sudan [though they abstained on the reauthorization of the ban].

None of these nations have taken any major action on the Cameroonian Crisis, despite the Communique and their ability to do so. However, considering the failures of West-driven intervention in the continent, these nations must have the conviction and courage to combat the pressing issue within their local territory.

\section{DOMESTIC NEGLECT}

In addition to the suppressed responses of the international community, the neglect that the Cameroon Crisis receives also extends to a domestic level. Most notable, this neglect can be seen through constant empty and benign statements about emphasizing peace and dialogue among Cameroonian authorities. When Cameroonian President Paul Biya 
Volume 8 Issue 9 September 2020

was re-elected on October 24, 2018, Global Affairs Canada released a statement that would encourage relevant Cameroonian government authorities and leaders to "engage in peaceful solutions to the crisis and put an end to the violence raging in the North West and southwest regions" [19]. This was to encourage the Cameroon government to implement important reforms to strengthen its legal framework and find long-term peaceful resolutions. The resolution of the conflict in Cameroon is critical in putting an end to its adverse impact on the social and economic situation in the country. However, any attempts engaging with internal dialogue when trying to address the human rights crisis have rendered largely ineffective. For example, after international pressures settled in, the Cameroonian Defence Ministry announced that there would be nationally coordinated investigations on the arson and destruction of property that is running rampant throughout the nation. Despite this internationally recognized announcement, very few investigations have been made to either punish or disincentivize human rights violators or criminals, let alone any initiatives to end impunity [12].

A similar pattern can be noted in the domestic efforts by Cameroon to broker peace in their internal conflict. One notable example is the establishment of the National Commission for the Promotion of Bilingualism and Multiculturalism [21]. This was an advisory body with financial autonomy that would be under the authority of the Cameroonian president. The NCPBM had three main objectives, 1) Maintaining peace 2) Reinforcing Cameroon's overall unity, and 3) Consolidating the willingness of the Cameroonian people to live together in peace and respect [18]. Despite being a body that should be functioning to reconcile the nation, the systems that are put in place are simply not working. The most recent session was held on July 14, 2017, and the entity has not coordinated any investigations. Besides, there have been no publications of the results of the internal efforts of the NCPBM, and no compensation has been provided for the victims of crimes violating their human rights.

This can also be noticed of the National Disarmament, Demobilization, and Reintegration Committee, which was established to receive and reintegrate repentant exfighters of Boko Haram and members of armed groups in the North-West and South-West Regions [22]. This includes the provision of training and other necessities to assist the ex-fighters to re-integrate into the civil society. However, just like the NCPBM, everything mentioned in the press release of this committee was false promises. According to the Raoul Wallenberg Centre for Human Rights (RWCHR), a Cameroonian lawyer expressed his concern that all of the government initiatives were "just a tool to show the international community that the government is committed to resolving conflict." [6]. Based on the publication of the Center for Human Rights Democracy in Africa, an Anglophone General Conference was established to propose solutions to the crisis in Cameroon. However, the Cameroonian government opposed these initiatives and prohibited the conferences from pushing through. Not only has the government neglected many of these domestic measures, but they have also shown some resistance against advancing their issue. The Anglophone General Conference (AGC) was a meeting that was coordinated by members of the clergy, religious leader, civil rights activists, politicians, and journals, led by Catholic Cardinal Christian Tumi to create and discuss robust solutions, with the Cameroonian Displacement Crisis. When there were attempts to propose solutions to the government, all of the initiatives were rejected, and all of the meetings organized by the AGC were even prohibited by Cameroon government authorities.

However, some elements have to be considered before criticizing the lack of initiatives, from both an international and domestic perspective. First of all, violence created by current armed secessionist groups has been terrorizing the local Cameroonian people. This conflict in tandem with the governmental conflict with Boko Haram in northern areas has triggered the need and establishment of a multinational joint task force. This multinational joint task force is working as a mediator to enforce the stabilization of this northern region. However, a report by US ambassador Jonathon Cohen discovers that the juxtaposition between the severe instability of south Cameroon and allocation of resources to the north ultimately jeopardizes the mutual objectives of both the Multinational Joint Task Force and the national government [5]. In his speech, Cohen expressed the high stakes in Cameroon should the crises remain unaddressed. As a country that is considered as an important ally against Islamic insurgencies, Cameroon in a very unstable condition may succumb to further threats from the Boko Haram and the Islamic State in West Africa [5]. Immediate intervention is necessary, which means that all sides are encouraged to convene in a peaceful dialogue to resolve the burgeoning crisis. 
Volume 8 Issue 9 September 2020

\section{COMPARATIVE STUDY}

International organizations and other countries cannot remain indifferent to the local conflicts of a particular country. It is not sensible to let a country in crisis be on their own, especially with the possible impact of wars on neighboring states. International intervention is necessary, given that members of the global community have to protect the common good of humanity. This was the case of Somalia, where various international organizations and developed countries helped in the adoption of a holistic approach to manage and resolve its conflict. In the same way, the crisis in Cameroon is an urgent matter that requires an international response and coherent measures. Some of the suggested steps for the conflict resolution is for the president of the republic to initiate recognition of the issues and step-up to pacify the increasing tension. In addition to the institutional reforms in the local government, the escalating conflict in Cameroon also requires an international response. However, a comparison of the Cameroonian Crisis with the Somalian crisis demonstrated that there is a lack of proportionality between the magnitude of the crises and the respective attention it receives.

\subsection{Somalia conflict victims}

Both Cameroon and Somalia experienced a crisis that receives international attention. These two countries had seen extreme violence and their people endured displacement amidst the conflicts. However, the conflicts and cases of displacement in these countries went through differing phases, mostly affected by the government's use of its resources and the global response to these issues. A comparison of some factors between the Cameroonian crisis and the Somalian crisis reveals that the former has experienced a more serious crisis compared to Somali. However, Cameroon did not receive adequate attention to address its problems compared to Somali.

In 2017, the report on the Somalia situation shows that there were about 2.4 million people of concern. This number is comprised of 1.5 million people who are displaced within Somalia and about 900,000 who seek refuge in nearby regions [27]. A factsheet published by the United Nations High Commissioner for Refugees (UNHCR) reveals that it is currently monitoring about 37,000 new internal displacements in Somalia. These number consists of people who are displaced because of conflict and insecurity, drought, and other reasons. The UNHCR fact sheet contains information that claims that there are about 35, 499 refugees and asylum seekers in Somalia, the majority of whom are from Ethiopia, Yemen, Syria, Tanzania, and Eritrea among others. Also, the fact sheet shows that armed conflict between Al Sunna WaJamma and Somali National Army resulted in 4,000 new displacements a month in Somalia [26].

Various factors contribute to conflicts in Somalia. These include the lack of government resources, limited access to humanitarian support presence, and poor infrastructure. The threatening impact of deprivation in Somalis is exacerbated by the insecurity caused by the Al Shabaab, especially in the South and Central region. According to the United Nations High Commissioner for Refugees, Somalia situation, Somalia is at a high risk of experiencing famine and displacement, putting 944,000 children to possible malnourishment.

\subsection{Cameroon conflict victims}

A report published in 2017 reveals that Cameroon had 639,304 people of concern, and still others who faced risks as a result of the continued Boko Haram strikes targeting civilians [20]. Based on the fact sheet, there was a decrease in the number of attacks against the villages, but reporters found the number of victims increasing with each attack. In February 2020, the United Nations High Commissioner for Refugees reported that Cameroon has 1,749,080 people of concern, a number that includes Central Africans, Nigerians, and returnees.

Cameroon is currently in dire need of assistance, especially in the North-Western region where NonState Armed Groups (NSAG) threaten to disrupt daily activities. The safety of the citizens is at risk due to the repeated clashes between the military and Non-State Armed Groups [26]. For example, an attack in Ngarbuh in February this year resulted in the killing of 24 people and the burning of houses. This forced the government defense to pursue the NSAG, a move that caused the displacement and killing of civilians in Fako, a division of Cameroon's Southwestern region.

The continuing conflict in Cameroon and the violence and abuses committed against the people is a pressing concern in the country. The country and its people suffered from thousands of human rights violations, from the burning of properties, killings, sexual abuse, child labor, and illegal arrests [16]. Many of the victims of abuse include children who suffered from trauma such as losing their family members and witnessing conflicts themselves. The survivors are in great need of medical attention and psychosocial support, in addition to shelter and basic items for their 
ISSN-2347-9698

Volume 8 Issue 9 September 2020

survival. Recent research reveals that the majority of the displaced members of the Cameroon population previously depended on livestock raising and agricultural production [16]. They were forced to flee from their villages due to the insurgencies and conflict between the Cameroon Army and the Non-State Armed Groups. This resulted in their lack of access to their main source of income and livelihood, thus increasing the threat to food scarcity affecting millions of people. Further, the conflicting parties have prevented the provision of education and health care to the public.

\subsection{Financial information and support for Somalia}

The UNHCR's Executive Committee reported a revised budget to address the Somalia situation in 2017 at $\$ 487.75$ million [27]. This amount is budgeted based on the UNHCR's program that intends to support and protection to displaced people in Somalia. The previous report reveals that many of the displaced people in Somalia seek refuge in host countries such as Ethiopia, Uganda, Yemen, and Kenya. In support of the host countries, the international community provided tangible aids for these countries to continuously support the refugees. For example, the Intergovernmental Authority on Development Assembly of Heads of State and Government held a conference in 2017 to develop an action plan to help refugees. In addition to African countries, the US served as one of the largest resettlement countries for the Somali refugees. The other countries that opened their doors as a resettlement area include Austria, Finland, Germany, Netherlands, and Canada [11]

Somalia is currently going through humanitarian and displacement crises, as a result of insurgencies, extreme weather, and locust infestation. In response, the EU and its Member States provided $€ 51.2$ million to fund humanitarian programs in Somalia. The humanitarian support from the EU helps in "funding support aid organizations delivering life-saving assistance to vulnerable people" [8]. Previously, the EU funded a project coursed through the Food and Agriculture Organization of the United Nations to address the locust outbreak and sustain the livelihood of the Somalian people. This is in addition to the mobilization of $€ 1.4$ million in the form of emergency assistance and the allocation of other funds to the World Health Organization to support the health authorities in Somalia scale up their readiness to respond to the health care needs of the people.

\subsection{Financial information and support for Cameroon}

Unfortunately, millions of people in Cameroon who experience humanitarian and displacement crises do not receive the needed support to allow them to live decently. This situation is exacerbated by the fact that the government of Cameroon is focused on maintaining the country's security and territorial integrity [13]. This resulted in limiting the Cameroonians to access humanitarian aids from supporting partners. The country primarily receive support from international organizations such as the United Nations, which acknowledged that about 1.3 million people in Cameroon require support and financial assistance [16]

According to the UNHCR, it received support financial contributions to help expedite programs for the displaced people in Cameroon. The earmarked contributions coming from the United States, CERF, Japan, and other donors reached up to 3.6 million [26]. The UNHCR requested funding for Cameroon as of March 2020 is $\$ 89.7$ million, but only about $12 \%$ of it is funded. Besides, the Office for the Coordination of Humanitarian Affairs adopted a humanitarian response plan for Cameroon in 2019, and "calls for \$298 million to provide for the millions in need" [16]. However, only about 9.1 percent of the amount requested was funded, as donors cited several obstacles that prevented them from providing the fund.

Further, out of the international humanitarian donors, only the EU and Canada expedited missions to fund the OCHA programs. Reports revealed that in 2019, the EU announced its intent to provide $€ 3$ million, while the US Foreign Disaster Assistance offered \$1 million for humanitarian support [16]. However, while these supports are welcome, the amount is grossly inadequate to resolve the displacement crisis in Cameroon. 
Volume 8 Issue 9 September 2020

\section{NEGLECT BY UNHCR AND}

\section{INTERNATIONAL ORGANIZATIONS}

Cameroon is suffering from a deepening but neglected crisis, given that the regional insurgency that arises from the Boko Haram insurgency is causing the displacement crisis in the country [20]. It did not receive adequate support from other countries and it is also neglected by the UN and other international organizations.

\subsection{Neglected set of objectives}

In a letter sent to the UN Security Council Members, the World Organisation Against Torture expressed their disappointment about the council's silence over the crisis. According to the OMCT, there is a lack of support from African member States and that Cameroon lacks access to "for international human rights and humanitarian organizations" [31]. In 2015, the UNHCR adopted strategies to provide protection and assistance to Cameroon [26]. However, a closer examination reveals that UNHCR set objectives for Cameroon operations, but failed to act on it to achieve the desired outcome.

The Finders Group Initiative executive director, Gaby Ambo fears that further neglect may result in grave consequences [23]. Recent reports reveal that the UNHCR failed to gather and provide adequate support to resolve the crisis:

UNHCR has launched an urgent appeal to increasesupport for displaced Cameroonians who havesurvived nearly two years of ongoing violence.But of the US\$184 million required for UNHCR's operations in Cameroonand Nigeria - including US\$35.4 million needed urgently for critical lifesaving assistance tonewly displaced Cameroonians just four percenthas been raised [30].

\subsection{Unrealistic goals}

The circumstances in Cameroon promoted the UNHCR to develop a response plan to address the needs of the different groups in the country. Initially, the organization focused on the immediate needs of the displaced people, which includes providing security, access to basic needs, and education [26]. For example, the planned activities include interventions that focus on offering education and improvement of school infrastructure. However, a 2019 report reveals that many children have not gone to school due to inadequate school capacity. While UNCHR adopted school projects and "added extensions to some schools to cater for more students, the numbers are still too high to accommodate them" [30]. As a result of the neglect, many Cameroonians have limited access to education, necessities, health care, and livelihood.

\subsection{The threat of the situation if not addressed}

The people in Cameroon are at a very dangerous crossroads. There is a dire need for humanitarian support in different parts of the country, however, the response appears limited [10]. In response, the United Nations High Commissioner for Refugees plans to construct new shelters for displaced people in Cameroon. Recent reports reveal that UNHCR has started to relocate refugees from congested sites to other camps.

It is noted that the failure of other countries and international organizations to respond to the crisis in Cameroon has had a significant implication, not only on the Cameroonians but also to the international community as a whole. Recent conflicts in Cameroon resulted in the burning of property, homes, and businesses, including the village development communities [25]. War is considered a development issue and its impact extends beyond killings and destruction of properties. A study on the consequence of local conflicts reveals that these have a long-term impact on civilian suffering. Thus, the sooner the displacement crisis and conflict in Cameroon is resolved, the better for the civilians.

\section{RECOMMENDED PLAN OF ACTION}

To directly tackle this issue, the international dialogue will have to be guided in a way that will allow more private-sector initiatives to take place. The international dialogue intends to come up with viable proposals to resolve the issue. In most instances, the failure in the attempts to resolve conflicts reveals the need for "a more reflexive attitude to conflict resolution" [24]. In an article published in the BBC News, proposals to address the crisis are important, as it will help "enhance participatory development across the country" [3]. It is noted that the violent conflict in Cameroon emerged as a result of the perceived inequality, repression, and marginalization of people in the Anglophone region [14]. Consequently, other countries and international organizations play a critical role in addressing and preventing the escalation of these conflicts.

\subsection{More international discussion}

The series of conflicts and humanitarian violations that were rampant in Cameroon since 2016 reflects the 
Volume 8 Issue 9 September 2020

deteriorating political, humanitarian, and security condition in the country [17]. These events are factors that are a cause of concern, not only of Cameroon and its neighboring countries but also of the global community. The intervention of international organizations is necessary as a means to consider all grievances. According to the International Crisis Group, "breaking the deadlock requires strong internal and international pressure" [19]. The international actors can intervene by encouraging the conflicting parties to engage in a peaceful dialogue.

\subsection{More initiatives/investigations}

The root cause of the Cameroonian conflict is associated with the colonial legacies of the French and British colonizers. During the 1960s, political elites from both parties agreed to form a federal state, which, resulted in a feeling of marginalization and exploitation on the part of the Anglophone region. In response, the government should acknowledge the existence of a problem, including the fact that government security forces have committed abuse against the Anglophone Cameroonians [19].

\subsection{Reforms}

One way by which the government can resolve the problem in Cameroon is to establish a comprehensive dialogue for both parties. This strategy will help address the conflict by allowing both parties to raise their concerns and to propose ways to resolve the.) For example, the government may offer its opinion with regards to the establishment of a multicultural system or a committee to research and report to the president about multiculturalism in the country.

This is a needed reform, such that the government is required to show its commitment by acknowledging the rights and preferences of the anglophone population. Part of the reform includes the provision of amnesty for protesters and their unconditional released from prison in this way the government can show that it recognizes the rights of its citizens towards by recognizing the right for peaceful protest [2].

\subsection{Realistic solutions}

An article entitled Lessons from the Past on Cameron's Crisis includes a commentary that says that a mediated negotiation appears to be the only means of achieving a realistic solution to the Cameroonian crisis [4]. An example of a conflict that was resolved after a mediated negotiation occurred between Ethiopia and Eritrea. The war between these two countries ended immediately after the United States intervened. The conflict in Cameroon can be resolved with the intervention of other countries and international organizations. In this way, the parties to the conflict will feel the responsibility and the pressure to engage in peaceful negotiation. An examination of events before the eruption of conflict reveals that the appointment of French-educated judges to the Anglophone region triggered strikes and demonstrations [17]. The realistic solution, therefore, is to encourage both parties to discuss and negotiate terms that best serve the interest of the Cameroonians.

\section{CONCLUSION}

The conflict in Cameroon's Anglophone region appears to be in a deadlock situation. The primary reason for this conflict is the inability of the two parties to engage in a peaceful dialogue. That is, the Government of Cameroon and the ex-British Southern Cameroonians are fighting to hold their ground and declined to discuss the best measures to address the current situation. The Government wants its way while the separatists want independence. The consequence of this conflict affects millions of people in Cameroon who suffer from atrocities, abuse, and displacement. Many people became homeless and children are deprived of their right to proper education because of the prolonged violence.

The prolonged conflict in Cameroon reflects the ability of the international community to resolve conflicts period. Moreover, many critics suggest that other countries and international organizations neglected Cameroon. They did not exert significant effort to help the country, much less to encourage both parties to come up with peaceful dialogue. The adverse impact of the conflict calls for international intervention, and for the different members of the international community to encourage their two parties to make concessions. A peaceful dialogue between the parties is an important factor that helps to eventually end the war and displacement crisis.

\section{REFERENCES}

[1]. Abdulla, Becky, et al. "The World's Most Neglected Displacement Crises." ReliefWeb Informing Humanitarians Worldwide, 2018, reliefweb.int/sites/reliefweb.int/files/resources/nrc s-list-of-the-worlds-most-neglected-displacementcrises.pdf.

[2]. Caxton, Ateki. "The Anglophone Dilemma in Cameroon - ACCORD." ACCORD, 24 July 2017, 
Volume 8 Issue 9 September 2020

www.accord.org.za/conflict-trends/anglophonedilemma-cameroon/.

[3]. Chimtom, Ngala K. "Will the Peace Plan End Cameroon's Conflict?" BBC News, 2019, www.bbc.com/news/world-africa-49931662.

[4]. Cohen, Herman. "Lessons From the Past on Cameroon's Crisis." Council on Foreign Relations, 2020, www.cfr.org/blog/lessons-pastcameroons-crisis.

[5]. Cohen, Jonathan. "Remarks at a UN Security Council Briefing on the Central African Region." U.S Mission to the United Nations, 2018, U.S Embassy in Mauritania. New York. Speech.

[6]. Cotler, Irwin. “Cameroon's Unfolding Catastrophe: Evidence of Human Rights Violations and Crimes Against Humanity." Raoul Wallenberg Centre for Human Rights, Raoul Wallenberg Centre for Human Rights, 3 June 2019, www.raoulwallenbergcentre.org/newsfeed/2019/6/ 4/release-of-landmark-report-on-unfoldingcatastrophe-in-cameroon.

[7]. Eliadis, Pearl, and Felix Nkongho. Cameroon's Unfolding Catastrophe: Contextualizing the Crisis. Queens University, 2019. globaljustice.queenslaw.ca/news/cameroonsunfolding-catastrophe-contextualizing-the-crisis

[8]. European Civil Protection and Humanitarian Aid. "Somalia." European Civil Protection and Humanitarian Aid Operations - European Commission, European Union, 2020, ec.europa.eu/echo/where/africa/somalia_en.

[9]. Global Affairs Canada. "Canadian Statement Following Cameroon's Constitutional Council's Decision on PresidentialElection." Canada.ca, 2018, www.canada.ca/en/globalaffairs/news/2018/10/canadian-statementfollowing-cameroons-constitutional-councilsdecision-on-presidential-election.html.

[10]. Global Report on International Displacement. Cameroon: A Deepening But Neglected Crisis. $2019 . \quad$ www.internaldisplacement.org/sites/default/files/publications/d ocuments/2019-IDMC-GRID-spotlightcameroon.pdf.

[11]. Hammond, Laura. Somali refugee displacements in the near region: Analysis and Recommendation. UNHCR Global Initiative on Somali Refugees, 2014. www.unhcr.org/55152c699.pdf.
[12]. Human Rights Watch. "Cameroon: Promised Investigation Should Be Independent." Human Rights

Watch, 2019, www.hrw.org/news/2019/05/23/cameroonpromised-investigation-should-be-independent.

[13]. Karimbhoy, Sara. "The Challenges of Emergency Response in Cameroon's Far North: Humanitarian Response in a Mixed IDP/refugee Setting." Humanitarian Practice Network, 2017, odihpn.org/magazine/the-challenges-ofemergency-response-in-cameroons-far-northhumanitarian-response-in-a-mixed-idprefugeesetting/.

[14]. Kiven, Gabriel N. "African Union Needs a More Robust Response to Conflict in Cameroon." The Conversation, 2020, theconversation.com/african-union-needs-a-morerobust-response-to-conflict-in-cameroon-132449.

[15]. Koning, Piet, and Francis Nyamjoh. "The Anglophone Problem in Cameroon." The Journal of Modern African Studies, vol. 35, no. 2, 1997.

116]. Lamarche, Alexandria, and Alanna Fox. "Crisis Denied in Cameroon." Refugees International, 2019,

eliefweb.int/sites/reliefweb.int/files/resources/Cam eroon\%2BReport\%2B-\%2BMay\%2B2019\%2B$\% 2 B f i n a l . p d f$.

[17]. Lunn, Jon, and Louisa Holland. The Anglophone Cameroon Crisis: April 2019 Update. House of Commons Library, 2019.

[18]. National Commission for the Promotion of Bilingualism and Multiculturalism. The NCPBM in Brief. 2017, www.cnpbm.cm/en/commission/ncpbm-brief.

[19]. Ntui, Arrey. "Cameroon." Crisis Group, International Crisis Group, 2018, www.crisisgroup.org/africa/centralafrica/cameroon.

[20]. Office for the Coordination of Humanitarian Affairs. UNHCR Cameroon Factsheet - October 2017 Cameroon. 2017. reliefweb.int/report/cameroon/unhcr-cameroonfactsheet-october-2017.

[21]. Republic of Cameroon. Decree No. 2017/013 of 23 January 2017 to Lay Down the Establishment, Organization and Functioning of the National Commission on the Promotion of Bilingualism and Multiculturalism.2017, www.prc.cm/en/multimedia/documents/5215- 
Volume 8 Issue 9 September 2020

decret-n-2017-013-du-23-01-2017-creationcnpbm-en.

[22]. Decree No.2018/719 of 30 November 2018 to Establish the National Disarmament, Demobilization and Reintegration Committee. 2018, www.prc.cm/en/multimedia/documents/6765decree-no-2018-719-of-30-11-2018-nddrc.

[23]. Searcey, Dionee. "As Cameroon English Speakers Fight to Break Away, Violence Mounts." The New York Times - Breaking News, World News \& Multimedia, 2018, www.nytimes.com/2018/06/28/world/africa/camer oon-secession.html.

[24]. Smidt, Wolbert, and Knife Abraham. Discussing Conflict in Ethiopia: Conflict Management and Resolution. LIT Verlag Munster, 2005.

[25]. Tembon, Efi. Crisis in the Republic of Cameroon: An Overview of the Anglophone Crisis. Cameroon Association for Bible Translation and Literacy, 2018.

[26]. United Nations High Commissioner for Refugees Global Appeal. Cameroon. UNHCR, 2015. www.unhcr.org/5461e5fce.pdf.
[27]. United Nations High Commissioner for Refugees. Somalia Situation 2017.2017. www.unhcr.org/591ae0e17.pdf.

[28]. UNHCR Cameroon - Factsheet - February 2020. United Nations, 27 Mar. 2020. data2.unhcr.org/en/documents/details/74865.

[29]. UNHCR Somalia Factsheet February 2020. 2020.

data2.unhcr.org/fr/documents/details/74970.

[30]. Wachiaya, Catherin. "Displaced Cameroonians Struggle in

Nigeria." UNHCR, 2019, www.unhcr.org/news/stories/2019/5/5cdbd9f74/di splaced-cameroonians-struggle-nigeria.html.

[31]. World Organisation Against Torture. "Cameroon : Civil Society Organizations Raise the Alarm over Deteriorating Human Rights Situation / June 6, 2019 / Reports and Publications / OMCT."World Organisation Against Torture (OMCT) - Global Network Fighting Against Torture and Other Human Rights Violations, 2019, www.omct.org/reports-andpublications/2019/06/d25374/ 